\title{
Okul Müdürlerinin Liderlik Stilleri ile Avrupa Birliği Projelerinin Okula Katkı Düzeyi Arasındaki ílişki ${ }^{1}$
}

\author{
Vefa Bardakcı \\ MEB-Türkiye \\ vefabardakci@hotmail.com
}

\author{
Prof. Dr. Ali Aksu \\ Dokuz Eylül Üniversitesi-Türkiye \\ ali.aksu@deu.edu.tr
}

\begin{abstract}
Özet:
Bu çalışmanın amacı, okul müdürlerinin liderlik stilleri ile Avrupa Birliği projelerinin okula katkı düzeyi arasındaki ilişkinin Ankara ili ortaokul öğretmenlerinin algılarına göre incelenmesidir. Araştırma ilişkisel tarama modelinde betimsel bir çalışmadır. Araştırmanın örneklemini 2016-2017 eğitim ve öğretim yulında Ankara ilinde yer alan en $a z$ bir $A B$ projesi yürütmüş ortaokullarda çalışan öğretmenler oluşturmaktadır. Bu araştırma kapsamında "Çok Faktörlü Liderlik Ölçeği" ve "AB Projeleri Katkıları Değerlendirme Ölçeği" kullanılmıştır. Okul müdürlerinin liderlik stillerine ilişkin sonuçlar incelendiğinde ögretmenlerin en yüksek düzeyde katılım gösterdikleri boyutun dönüşümcü liderlik olduğu, en düşük ortalamanın ise serbestlik tanıyan liderlik boyutunda gerçekleştiği görülmüştür. Araştırma sonucunda $A B$ projesi yürütülen okullardaki ögretmenlerin bu projelerin katkılarına ilişkin algılarının olumlu olduğu görülmüştür. Öte yandan bu algıların öğretmenlerin cinsiyetine ve öğrenim düzeyine göre farkllık göstermediği gözlenmiştir. Araştırma kapsamında yapılan çoklu doğrusal regresyon analizi sonucunda dönüşümcü liderlik ve serbestlik tanıyan liderlik alt boyutlarının AB projelerinin okula katkı düzeyini anlamlı biçimde yordadığı görülmüştür.
\end{abstract}

Keywords: Okul, Liderlik, Liderlik stilleri, AB projeleri

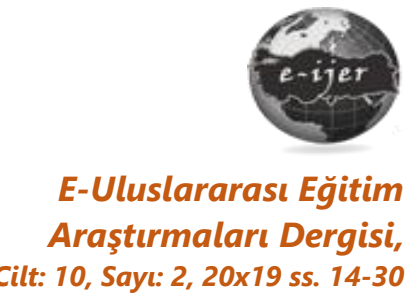

DOI: $10.19160 /$ ijer.468460

\section{Önerilen Atıf}

Bardakçı, V. \&. Aksu, A. (2019). Okul Müdürlerinin Liderlik Stilleri ile Avrupa Birliği Projelerinin Okula Katkı Düzeyi Arasındaki Iliş̧ki, E-Uluslararası Eğitim Araştırmaları Dergisi, Cilt: 10, Sayı: 2, 2019, ss. 14-30, DOI: 10.19160/ijer.468460

\footnotetext{
${ }^{1}$ Bu çalışma ilk yazarın, ikinci yazar danışmanlığında tamamladığı, yüksek lisans tezinden üretilmiştir.
} 


\section{Giriş}

Toplumun kültürel, siyasal ve ekonomik ihtiyaçlarının karşılanması doğrultusunda nitelikli insan gücünün yetiştirilmesi eğitimin önemli işlevleri arasında yer almaktadır. Bu çerçevede, eğitim sistemini çağdaş gelişmelere uygun bir şekilde geliştirme çabası, eğitim reformlarının öncelikleri arasında yer almaktadır. Bu yöndeki girişimler, küresel ölçekte imzalanan çeşitli antlaşmalarla teyit edilmiştir. Söz konusu antlaşmalar, öğrencilerin toplumun gerek gördüğü temel yeterlikleri kazanacak biçimde eğitimlerini tamamlamalarını amaçlamaktadır (Council of the European Union, 2003, 2009; UN, 2003; UNESCO, 2000, 2014; WCEFA, 1990). Ayrıca, küresel ölçekte izleme ve değerlendirme çalışmaları ile birlikte belirlenen bu hedeflere ulaşıı ulaşılamadığına ilişkin sonuçlar performans karnesi niteliğinde dönütler sunmaktadır (Kavak, 2010; Toprakcı ve Yılmaz, 2014).

Avrupa birliğinin eğitim alanında belirlediği amaçları vardır. Bu amaçlar üye ve aday ülkeler nezdinde gerçekleştirilmesi planlanan bir takım hedefleri kapsamaktadır (Toprakcl, 2004). Hedefler, erken yaşta okulu bırakma oranını \%10'dan daha düşük bir seviyeye indirme, yükseköğretime erişimi 2020 yılına kadar en az \%40 seviyelerine çıkarma vb. şeklinde ifade edilebilir. Avrupa Birliği, eğitim hedefleri kapsamında insanlık onuru, özgürlük, demokrasi ve eşitlik gibi kişisel haklara vurgu yapmakta, insanların haklarına saygıyı öngören değerleri ön plana çıkarmakta ve eşitliğin hâkim olduğu bir toplum oluşturma vizyonunu ortaya koymaktadır (Ulusal Ajans [UA], 2014). Bu hedefler doğrultusunda AB komisyonu 25 yıldır çeşitli programlar altında eğitim, öğretim ve gençlik alanında projeler yürütmektedir. Avrupa Konseyinin hedefleri doğrultusunda Türkiye'de yapılan okul projeleri, okul paydaşları arasında ilişkiyi geliştiren, birlikte çalışabilme kabiliyeti kazandıran, velilerin okul faaliyetlerine katılımını arttıran, proje çalışmalarına katılan öğrencilerin akademik, sosyal ve sanatsal alanlarda çalışmalara dâhil olmasını sağlayan, öğrencilere öğrendiklerini sergileme imkânı vererek öğrencilerin özgüven duygusunu geliştiren, katılımcıların, sadece $A B$ üyesi ülkelerinin değil aynı zamanda kendi ülkelerinin değerlerini öğrenme ve araştırma fırsatı sağlayan, dil öğrenimini teşvik eden bir girişim olarak görülmektedir (Aydoğmuş, 2013; Kulaksız, 2010; Öztürk, 2015; Toprakcı, 2006). Bu fırsatları sunan ve iyi yönetilen okul projelerinin, okullara birçok alanda katkı sağlayacağı öngörülebilir. Bu sebeple, okul müdürlerinin liderlik stillerinin, projelerin devamlılığı ve $A B$ projelerinin okullara sağladığı katkı açııından incelenmesi önemli görülmektedir. Bu projelerin gerçekleştirileceği okulların okul müdürleri de bu nedenle önemli bir faktör olarak karşımıza çıkmaktadır. Bu çerçevede, çalışmanın problem durumunda, $A B$ projelerinin yürütüldüğü okullarda görev yapan okul müdürlerinin liderlik stilleri bir faktör olarak yer almaktadır.

Okul müdürlerinin sergiledikleri liderlik stilleri, okulun yer aldığı sürecin, faaliyetin veya projenin performansını etkilemektedir. Okullarda düzenlenen $A B$ projeleri kapsamında okul eğitimi faaliyetleri okul müdürünün liderliği ve desteği ile sürdürülmektedir. Bu durum projelerin yürütülmesinde okul müdürünü önemli bir paydaş haline getirmektedir. $A B$ projeleri yürüten okulların, projelerin yürütülmesi için uygun ortam oluşturabilme, sürekli işbirliği ve destek sağlama, mesleki gelişim için destek verme, dayanışma ortamı oluşturma, öğrencilere destek sağlama, değişme açık olma, olumlu okul-topluluk ilişkileri oluşturma, ortak karar alma süreci sürdürme, okul yöneticileri, öğretmenler ve velilerin ilgi düzeyinin yüksek olması gibi özellikleri olduğu bilinmektedir (Burgaz ve Turan, 2015). Bu nedenle, bu okulların müdürlerinin de okullarının $A B$ projelerinin gerçekleştirilebileceği sağlıklı bir ortam sağlama konusunda liderlik etmeleri beklenmektedir. Bir projedeki dönüştürücü liderlik, proje ekibinin diğer üyelerini ve herkes için gerçek sonucu arayan dış katılımcıları olumlu yönde etkileme yeteneğidir. Janiunaite 
(2005) $A B$ projelerinin yürütüldüğü okullarda okul müdürünün sergilemesi gereken liderlik özelliklerini şu şekilde açıklamaktadır: a) ortaklar arasında iletişimin ve bilgi paylaşımının başlatılması, güçlendirilmesi ve teşvik edilmesi; b) birlikte çalışmak için ekip kurulması ve ekibin motive edilmesi; c) tüm ekip üyelerinin projenin amaçlarını gerçekleştirmeye dahil edilmesi; d) ortak sonuçlar için görev ve sorumluluğun devredilmesi; e) paydaşların, Avrupa ortaklığının kurum için sağlayabileceği avantajlara ikna edilmesi; f) program çıktılarının değerlendirilmesi. Başka bir deyişle, okul müdürünün güçlü ve ilham verici özelliklere sahip bir lider olması beklenmektedir.

$A B$ projelerine katılım sağlayan okullarda görev yapan öğretmen ve okul yöneticilerinin projelerdeki rolü ve katkılarını ele alan çalışmalar, bu çalışma için bir rehber niteliğinde görülmektedir (Gülsen, 2008; Kamber, 2007). Diğer taraftan, ilgili literatüre farklı bir katkı sağlamak amacıyla yapılan bu çalışmada ise okul müdürlerinin liderlik stilleri de bu değerlendirme kapsamına dâhil edilmiştir. Ayrıca bu değerlendirmelerin AB projelerine katılım gösteren ve göstermeyen öğretmenler arasında yapılmasının da, $A B$ projelerinin etkililiğini değerlendirmek amacıyla oldukça yararlı olacağı düşünülmektedir. Bu amaçla araştırma sonucunda elde edilen bulgular, okullara $A B$ projelerinin etkilerini aktarmada rehber olacaktır. Ayrıca, $A B$ projesi başvurularında okul yöneticilerinin "Yasal Temsilci" unvanı ile yer alması, yöneticilerin liderlik stillerinin de $A B$ proje değerlendirmelerinde önemli bir basamağı temsil ettiğini göstermektedir. Ayrıca, bu araştırma konusunun incelendiği başka araştırmalara rastlanmamıştır. Bu açıdan değerlendirildiğinde, çalışmanın alanyazında önemli bir boşluğu dolduracağı düşünülmektedir.

Araştırmanın problem cümlesi $A B$ projesi yürütülen okullardaki öğretmenlerin bu projelerin katkılarına ve okul müdürlerinin liderlik stillerine ilişkin algıları nedir; öğretmenlerin algıları bazı değişkenlere göre anlamlı bir farklııı göstermekte midir, öğretmenlerin $A B$ projelerinin katkılarına ve okul müdürlerinin liderlik stillerine ilişkin algıları arasındaki ilişkiler nelerdir? şeklinde belirlenmiştir. Bu doğrultuda, aşağıdaki alt problemlere cevap aranmaktadır:

1. $A B$ projesi yürütülen okullardaki öğretmenlerin bu projelerin katkılarına ilişkin algıları ne düzeydedir? Bu algılar, öğretmenlerin cinsiyetine, mesleki kıdemine, branşına, $A B$ proje faaliyetlerinde yer alma durumuna ve öğrenim düzeyine göre anlamlı bir farklılık göstermekte midir?

2. $A B$ projesi yürütülen okullardaki öğretmenlerin görev yaptıkları okulların müdürlerinin liderlik stillerine yönelik algıları ne düzeydedir? Bu algılar, öğretmenlerin cinsiyetine, mesleki kıdemine, branşına, $A B$ proje faaliyetlerinde yer alma durumuna ve öğrenim düzeyine göre anlamlı bir farklılık göstermekte midir?

3. $A B$ projesi yürütülen okullardaki öğretmenlerin $A B$ projelerinin okula katkılarına ve okul yöneticilerinin liderlik stillerine yönelik algıları arasında anlamlı bir ilişki var mıdır?

4. $A B$ projesi yürütülen okullardaki öğretmenlerin algılarına göre okul yöneticilerinin liderlik stilleri $A B$ projelerinin okula katkı düzeyinin anlamlı bir yodayıcısı mıdır?

\section{YÖNTEM}

\section{Araştırma modeli:}

$\mathrm{Bu}$ araştırma ile Ankara illinde yer alan ve $A B$ projesi yürütmüş okullardaki öğretmenlerin algılarına göre $A B$ projelerinin okula katkı düzeyi ile okul müdürlerinin liderlik stilleri arasındaki ilişki ve bunların bağlı olduğu değişkenlerin saptanması amaçlandığından, araştırma ilişkisel tarama modelinde betimsel bir çalışmadır. Tarama modeli, araştırılmak istenen bir durumun var olduğu şekliyle betimlenmesidir. illişkisel tarama modeli ise iki veya daha fazla sayıdaki değişkenin birlikte değişimini ve bu değişimin derecesini ortaya çıkarmayı amaçlamaktadır (Karasar, 2009). 


\section{Evren ve örneklem:}

Araştırmanın evreni, 2016-2017 eğitim öğretim yılında Ankara'da yer alan en az bir Avrupa Biliği projesine katılmış okullar olarak belirlenmiştir. $A B$ projesi yürütmüş okullar Ulusal Ajans aracılığıyla elde edilen listeye dayalı olarak belirlenmiş, diğer okullar araştırma dışı bırakılmıştır. Edinilen bilgiler doğrultusunda, Erasmus + kapsamında 2014 yılında 10, 2015 yılında 4 ve 2016 yılında 7 projenin kabul edildiği görülmüştür. Bu doğrultuda araştırmanın evrenini 21 resmi ortaokulda görev yapan toplam 971 öğretmene oluşturmaktadır. Araştırmada evrenin tamamına ulaşılmak istenmiş, evrene ulaşma oranı \%80,1 olarak gerçekleşmiştir. Araştırmada yer alan öğretmenlerin büyük çoğunluğu $(\% 71,4)$ kadındır. Kişisel bilgiler kıdem açısından incelendiğinde, 1-5 yıllık kıdeme sahip öğretmenlerin örneklemin \% 16,8'ini; 6-20 yıllık kıdeme sahip öğretmenlerin öğretmenlerin örneklemin \%53.9' unu; 21 ve üzeri kıdeme sahip öğretmenlerin ise örneklemin \%29,3 'ünü oluşturduğu görülmektedir. Öğretmenlerin eğitim düzeyi incelendiğinde, $\% 1,9^{\prime}$ u ön lisans, \%90,9'u lisans ve \%7,3'ü yüksek lisans mezunudur. Öte yandan, öğretmenlerin $\% 30,0$ 'u $A B$ projeleri faaliyetlerine katılmıştır.

\section{Veri toplama araçları:}

Araştırmanın verilerine ulaşmak için "Çok Faktörlü Liderlik Ölçeği" ve "AB Projeleri Katkıları Değerlendirme Ölçeği" kullanılmıştır. Belirtilen ölçeklerin çalışma kapsamında kullanılması için eposta aracııı̆ıyla izin alınmıştır. İzinler alındıktan sonra 3 bölümden oluşan bir form oluşturulmuştur. Bu formun ilk kısmında öğretmenlerin kişisel bilgilerini (cinsiyet, mesleki kıdem, branş, $A B$ proje faaliyetlerinde yer alma durumu, öğrenim düzeyi) saptamaya dönük ifadeler, ikinci bölümde ise 36 maddelik Çok Faktörlü Liderlik Ölçeği, üçüncü ve son bölümde ise $A B$ Projeleri Katkıları Değerlendirme Ölçeği yer almaktadır.

Çok Faktörlü Liderlik Ölçeği (MLQ): Çok Faktörlü Liderlik Ölçegi (MLQ), 1985 yılında Bernard Bass tarafından geliştirilmiş olup liderlik stillerini çeşitli faktörler açısından incelemek üzere hazırlanmıştır. Aksu (2015) tarafından veri toplama aracının Türkçeye uyarlama çalışması yapılmış, dil geçerliği .99 olarak bulunmuştur. Ölçekte dönüşümcü liderlik $(2,6,8,9,10,13,14$, $15,18,19,21,23,25,26,29,30,31,32,34,36)$ ile ilgili 20 madde, etkileşimci liderlik $(1,4,11,16$, $22,24,27,35)$ ile ilgili 8 madde, serbestlik tanıyan liderlik $(3,5,7,12,17,20,28,33)$ ile ilgili 8 madde yer almakta olup, ölçek toplam 36 maddeden oluşmaktadır. Aksu'nun (2014) çalışmasında, ölçeğin Cronbach Alpha güvenirlik katsayıları dönüşümcü liderlik boyutunda .94; etkileşimci liderlik boyutunda .88 ve serbestlik tanıyan liderlik boyutunda ise .92 olarak bulunmuş̧ur. Ölçeğin tamamının güvenirliği ise, .94 'tür. DFA sonuçlarına göre RMSEA değeri 0,07; Üç liderlik stilini ele alan ölçek yapısının araştırma kapsamında toplanan verilerle doğrulanmasına dönük analiz için LISREL programı kullanılmıştır. ki-kare/sd değeri 4,54 düzeyinde kabul edilebilir olup, RMSEA değeri ise 0,07 olarak gerçekleşmiştir. Diğer taraftan, ölçeğin güvenirlik katsayısı .83 'tür. Tüm bu bilgiler değerlendirildiğinde, ölçeğin araştırma verileri açısından geçerli ve güvenilir olduğu söylenebilir.

AB Projeleri Katkıları Değerlendirme Ölçeği: Kesik ve Balcı (2015) tarafından geliştirilen ölçek, $A B$ projelerine katılım sağlayan okullarda, projenin okula olan katkılarının değerlendirilmesi amacıyla oluşturulmuştur. Cronbach Alfa güvenirlik analizleri sonucunda 31 maddeden oluşan ölçek yüksek derecede güvenilir $(\alpha=0,96)$ bulunmuştur. Ölçek, "Kurumsal Gelişim" (13 madde), "Kişisel/Mesleki Gelişim" (7 madde), "Sosyal Gelişim" (5 madde), Yabancı Dil Öğrenme" (4 madde) ve "Kültürel Gelişim" (2 madde) boyutlarından oluşmaktadır. . Ölçek formunda yer alan her madde $5^{\prime}$ li Likert tipindedir. Ölçeğin yapısı yukarıda sıralanan bilgiler 
doğrultusunda kuramsal açıdan test edildiğinden, bu araştırmanın verileri açısından geçerliliği sağlayıp sağlamadığı DFA ile incelenmiştir. Ki-kare/sd değeri 4,99 düzeyinde kabul edilebilir olup, RMSEA değeri ise 0,077 olarak gerçekleşmiştir. Diğer taraftan, ölçeğin güvenirlik katsayısı .97' dir. Tüm bu bilgiler değerlendirildiğinde, ölçeğin araştırma verileri açısından geçerli ve güvenilir olduğu söylenebilir.

\section{BULGULAR}

\section{AB projesi yürütülen okullardaki öğretmenlerin bu projelerin okullarına sağladığı katkılara ilişkin algıları ne düzeydedir?}

$A B$ projesi yürütülen okullardaki öğretmenlerin bu projelerin katkılarına ilişkin algıları ne düzeydedir? sorusuna cevap bulmak amacıyla yapılan betimsel istatistik analizine ilişkin bulgular Tablo 1.'de yer almaktadır.

Tablo 1. Öğretmenlerin AB Projelerinin Katkılarına ilişskin Algılarına Ait Betimsel Istatistikler

\begin{tabular}{rccc}
\hline Alt boyutlar & $\mathbf{N}$ & $\overline{\mathbf{X}}$ & sh \\
\hline Kurumsal Gelişim & 668 & 4,41 & 0,02 \\
\hline Kişisel/Mesleki Gelişim & 668 & 4,15 & 0,03 \\
\hline Sosyal Gelişim & 668 & 4,21 & 0,03 \\
\hline Yabancı Dil Öğrenme & 668 & 4,11 & 0,03 \\
\hline Kültürel Gelişim & 668 & 3,98 & 0,03
\end{tabular}

Tablo 1. incelendiğinde, $A B$ projesi yürütülen okullardaki öğretmenlerin bu projelerin katkılarına ilişkin algılarının ölçeğin alt boyutlarına göre ortalamasının olumlu olup, standart hata değerlerinin ise çok düşük olduğu görülmektedir. Buna göre öğretmenlerin en yüksek düzeyde katılım gösterdikleri boyut kurumsal gelişim $(\bar{X}=4,41)$ olurken en düşük ortalama ise kültürel gelişim $(\bar{X}=3,98)$ boyutunda gerçekleşmiştir.

$A B$ Projeleri Katkıları Değerlendirme Ölçeği'nden elde edilen verilerin cinsiyetine, mesleki kıdemine, branşına, $A B$ proje faaliyetlerinde yer alma durumuna ve öğrenim düzeyine göre farklılaşma durumunun saptanması için yapılan t-testi ve tek yönlü varyans analizine ait bulgular şöyledir: AB projesi yürütülen okullardaki öğretmenlerin bu projelerin katkılarına ilişkin algılarının ölçeğin alt boyutlarında cinsiyete göre anlamlı bir fark olmadığı görülmektedir (t $(642)=.30, t$ $(642)=1.03, \mathrm{t}(642)=1.18, \mathrm{t}(642)=1.41, \mathrm{t}(642)=1.33, \mathrm{t}(642)=.98, \mathrm{p}>.05)$. Bu kapsamda, $A B$ projesi yürütülen okullardaki öğretmenlerin bu projelerin katkılarına ilişkin algılarının kadın ve erkeklerde benzer düzeyde olduğu söylenebilir. Öte yandan, $A B$ projesi yürütülen okullardaki öğretmenlerin bu projelerin katkılarına ilişkin algılarının ölçeğin Kişisel/Mesleki Gelişim, Sosyal Gelişim, Yabancı Dil Öğrenme ve Kültürel Gelişim alt boyutlarında mesleki kıdeme göre anlamlı bir fark olmadığı görülmektedir $(F(2,639)=.84, F(2,639)=1.00, F(2,639)=2.70, F(2,639)=2.09$, $p>$.05). Bu bulgu, farkıı kıdeme sahip öğretmenlerin, $A B$ projelerinin katkılarına ilişkin algılarının ölçeğin kişisel/mesleki gelişim, sosyal gelişim, yabancı dil öğrenme ve kültürel gelişim alt boyutlarını benzer biçimde algıladıkları şeklinde değerlendirilebilir. Diğer taraftan, ölçeğin kurumsal gelişim alt boyutunda ise mesleki kıdeme göre anlamlı bir fark olduğu görülmektedir $\left(F_{(2,639)}=3.50, p<.05\right)$. Buna göre, öğretmenlerin kıdemine göre oluşan bu farklılığın hangi gruplar arasında gerçekleştiğini bulmak üzere yapılan LSD testi sonucuna göre farkın 6-20 yıl $(\bar{X}=4,45)$ arasında kıdeme sahip öğretmenlerde, 21 ve üzeri yıl ( $\bar{X}=4,31$, çoğu zaman) kıdeme sahip öğretmenlere göre daha yüksek olduğu görülmektedir $(p<0,01)$.

$A B$ projesi yürütülen okullardaki öğretmenlerin bu projelerin katkılarına ilişkin algılarının ölçeğin kurumsal gelişim alt boyutunda branşa göre anlamlı bir fark olduğu görülmektedir $\left(F_{(12,596)}=1.98, p<.05\right)$. Buna göre, öğretmenlerin branşına göre oluşan bu farklılı̆ın hangi 
gruplar arasında gerçekleştiğini bulmak üzere yapılan LSD testi sonucuna göre sosyal bilgiler $(\bar{X}=4,39)$ ve görsel sanatlar $(\bar{X}=4,47)$ branşında görevli öğretmenlerin algılarının teknoloji ve tasarım branşındakilere $(\bar{X}=4,13)$ göre daha yüksek olduğu görülmektedir. Ayrıca, Türkçe $(\bar{X}=4,42)$, matematik $(\bar{X}=4,44)$ ve yabancı dil $(\bar{X}=4,50)$ branşında görevli öğretmenlerin algılarının teknoloji ve tasarım $(\bar{X}=4,13)$ ve din kültürü ve ahlak bilgisi branşındakilere $(\bar{X}=4,21)$ göre daha yüksek olduğu izlenmektedir. Bunun yanında, fen bilimleri branşında görevli öğretmenlerin algılarının $(\bar{X}=4,55)$ teknoloji ve tasarım $(\bar{X}=4,13)$, din kültürü ve ahlak bilgisi $(\bar{X}=4,21)$ ve rehberlik branşındakilere $(\bar{X}=4,22)$ göre daha yüksek olduğu izlenmektedir.

$A B$ projesi yürütülen okullardaki öğretmenlerin bu projelerin katkılarına ilişkin algıları ölçeğin kişisel/mesleki gelişim, sosyal gelişim, yabancı dil öğrenme ve kültürel gelişim alt boyutlarında ab proje faaliyetlerinde yer alma durumuna göre anlamlı bir fark olmadığı, kurumsal gelişim alt boyutunda ise anlamlı bir fark olduğu görülmektedir ( $\mathrm{t}\left({ }_{(645)}=2.69, \mathrm{p}<.05 ; \mathrm{t}\right.$ $\left.{ }_{(645)}=0.07, \mathrm{t}_{(645)}=0.09, \mathrm{t}_{(645)}=0.23, \mathrm{t}_{(645)}=0.95, \mathrm{t}_{(645)}=0.04, \mathrm{p}>.05\right)$. Bu kapsamda, kurumsal gelişim boyutuna ilişkin öğretmen algılarının proje faaliyetlerinde yer alanlar lehine daha yüksek olduğu söylenebilir. Bununla birlikte, $A B$ projesi yürütülen okullardaki öğretmenlerin bu projelerin katkılarına ilişkin algılarının ölçeğin kurumsal gelişim, kişisel/mesleki gelişim, sosyal gelişim, yabancı dil öğrenme ve kültürel gelişim alt boyutlarında öğrenim düzeyine göre anlamlı bir fark olmadığı görülmektedir $\left(\mathrm{F}_{(2,644)}=.73, \mathrm{~F}_{(2,644)}=.68, \mathrm{~F}_{(2,644)}=.81, \mathrm{~F}_{(2,644)}=.56, \mathrm{~F}_{(2,644)}=.20\right.$ $p>.05)$.

\section{AB projesi yürütülen okullardaki öğretmenlerin görev yaptıkları okulların müdürlerinin liderlik stillerine ilişkin algıları ne düzeydedir?}

Tablo 2.Öğretmenlerin Görev Yaptıkları Okulların Müdürlerinin Liderlik Stillerine Illişkin Algılarına Ait Betimsel Istatistikler

\begin{tabular}{rlll}
\hline Alt boyutlar & $\mathbf{N}$ & $\overline{\mathbf{X}}$ & sh \\
\hline Dönüşümcü liderlik & 668 & 4,24 & 0,02 \\
\hline Etkileşimci liderlik & 668 & 3,84 & 0,02 \\
\hline Serbestlik tanıyan liderlik & 668 & 2,27 & 0,03 \\
\hline
\end{tabular}

Tablo 2. incelendiğinde, $A B$ projesi yürütülen okullardaki öğretmenlerin görev yaptıkları okulların müdürlerinin liderlik stillerine ilişkin algılarının sırasıyla dönüşümcü liderlik ve etkileşimci liderlik boyutunda yüksek olduğu, standart hata değerlerinin ise çok düşük olduğu görülmektedir. Buna göre öğretmenlerin en yüksek düzeyde katılım gösterdikleri boyut dönüşümcü liderlik $(\bar{X}=4,24)$ olurken en düşük ortalama ise serbestlik tanıyan liderlik $(\bar{X}=2,27)$ boyutunda gerçekleşmiştir.

Söz konusu öğretmen algıları cinsiyet değişkeni açısından incelendiğinde, $A B$ projesi yürütülen okullardaki öğretmenlerin görev yaptıkları okulların müdürlerinin liderlik stillerine ilişkin algılarının, ölçeğin dönüşümcü liderlik ve etkileşimci liderlik alt boyutlarında cinsiyete göre anlamlı bir fark olduğu görülmektedir $\left(\mathrm{t}_{(642)}=-2.10, \mathrm{t}_{(642)}=-3.30, \mathrm{p}<.05\right)$. Buna göre, dönüşümcü liderlik boyutunda, erkek öğretmenlerin algıları $(\bar{X}=4,31)$ kadın öğretmenlere göre $(\bar{X}=4,21)$ daha yüksektir. Benzer biçimde, etkileşimci liderlik boyutunda erkek öğretmenler $(\bar{X}=3,96)$ kadınlara göre $(\bar{X}=3,80)$ daha yüksek puana sahiptir. Bu durum, söz konusu iki liderlik yaklaşımının erkekler tarafından daha olumlu algılandığı biçiminde yorumlanabilir. Öte yandan, ölçeğin serbestlik tanıyan liderlik alt boyutunda ise anlamlı bir fark olmadığı görülmektedir (t ${ }_{(642)}$ $=-3.02, p>.05)$. Bu boyutta erkek ve kadın öğretmenlerin algılarının benzer düzeyde olduğu 
söylenebilir. Diğer taraftan, $A B$ projesi yürütülen okullardaki öğretmenlerin görev yaptıkları okulların müdürlerinin liderlik stillerine ilişkin algılarının ölçeğin dönüşümcü liderlik, serbestlik tanıyan liderlik ve etkileşimci liderlik alt boyutlarında mesleki kıdeme göre anlamlı bir fark olmadığı görülmektedir $\left(\mathrm{F}_{(2,639)}=.37, \mathrm{~F}_{(2,639)}=1.99, \mathrm{~F}_{(2,639)}=1.23, \mathrm{p}>.05\right)$.

Bununla birlikte, $A B$ projesi yürütülen okullardaki öğretmenlerin görev yaptıkları okulların müdürlerinin liderlik stillerine ilişkin algıları, ölçeğin dönüşümcü liderlik, serbestlik tanıyan liderlik ve etkileşimci liderlik alt boyutlarında branşa göre anlamlı bir fark olmadığı görülmektedir $\left(F_{(12,596)}=.66, F_{(12,596)}=.41, F_{(12,596)}=.43, p>.05\right)$. Ayrıca, $A B$ projesi yürütülen okullardaki öğretmenlerin görev yaptıkları okulların müdürlerinin liderlik stillerine ilişkin algılarının, ölçeğin serbestlik tanıyan liderlik, dönüşümcü liderlik ve etkileşimci liderlik alt boyutlarında $A B$ proje faaliyetlerinde yer alma durumuna göre anlamlı bir fark olmadığı görülmektedir ( $t_{(645)}=1.87, \mathrm{t}$ $\left.{ }_{(645)}=0.60, \mathrm{t}_{(645)}=-0.54, \mathrm{p}>.05\right)$. Yine, $\mathrm{AB}$ projesi yürütülen okullardaki öğretmenlerin görev yaptıkları okulların müdürlerinin liderlik stillerine ilişkin algıları, ölçeğin dönüşümcü liderlik, serbestlik tanıyan liderlik ve etkileşimci liderlik alt boyutlarında öğrenim düzeyine göre anlamlı bir fark olmadığı görülmektedir $(F(2,644)=.66, F(2,644)=.42, F(2,644)=.99, p>.05)$.

Araştırmanın üçüncü alt probleminde $A B$ projesi yürütülen okullardaki öğretmenlerin $A B$ projelerinin okula katkılarına ve okul yöneticilerinin liderlik stillerine ilişkin algıları arasında anlamlı bir ilişki olup olmadığı incelenmiştir. Bu çerçevede, Çok Faktörlü Liderlik Ölçeğinden elde edilen okul yöneticilerinin liderlik stillerine ilişkin algıları ve $A B$ Projeleri Katkıları Değerlendirme Ölçeğinden elde edilen $A B$ projelerinin okula katkılarına ilişkin algıları arasında yapılan Pearson Korelasyon Analizi sonuçları Tablo 3'te verilmiştir.

Tablo 3. Çok Faktörlü Liderlik Ölçeği ve AB Projeleri Katkıları Değerlendirme Ölçeği'ne ait Korelasyon Değerleri

\begin{tabular}{|c|c|c|c|c|c|c|c|c|c|}
\hline Değişkenler & $N$ & $\bar{X}$ & ss & 1 & 2 & 3 & 4 & 5 & 6 \\
\hline Çok Faktörlü Liderlik Ölçeği (1) & 668 &, $71^{\mathrm{a}}$ & 39 & & & & & & \\
\hline Dönüşümcü liderlik (2) & 668 & $24^{a}$ & 55 &, $853^{* *}$ & & & & & \\
\hline Etkileşimci liderlik (3) & 668 & $84^{\mathrm{a}}$ & 56 &, $756 * *$ &, $537 * *$ & & & & \\
\hline Serbestlik tanıyan liderlik (4) & 668 & $27^{\mathrm{a}}$ & 71 &, $210 * *$ & $263^{* *}$ &, 035 & & & \\
\hline AB Projeleri Katkıları Değerlendirme Ölç. (5) & 668 & $25^{\mathrm{b}}$ & 61 &, $362 * *$ & ,390** &, 196 ** & 0,02 & & \\
\hline Kurumsal Gelişim (6) & 668 & $41^{\mathrm{b}}$ & 58 & ,310** &, $352^{* \star}$ &, $151^{\star *}$ & 0,041 &, $912^{\star *}$ & \\
\hline Kişisel/Mesleki Gelişim (7) & 668 & $15^{\mathrm{b}}$ & 72 &, $334^{* *}$ &, $345^{\star *}$ &, $195^{\text {** }}$ & 0,001 &, $941^{* *}$ & $811^{\star \star}$ \\
\hline Sosyal Gelişim (8) & 668 & ${ }_{1,21^{b}}$ & 71 & $327^{* *}$ & $352^{* *}$ & $188^{* *}$ & 0,029 & $895^{* *}$ &, $712^{* *}$ \\
\hline Yabancı Dil Öğrenme (9) & 668 &, $11^{\mathrm{b}}$ & 80 &, $359 * *$ &, $379 * *$ & $199 * *$ & 0,009 & $889 * *$ &, $689^{* *}$ \\
\hline Kültürel Gelişim (10) & 668 & $98^{b}$ & 86 & ,318** &, $318^{* *}$ &, $175^{\star *}$ & ,029 &, $775^{\star *}$ &, $53^{\star *}$ \\
\hline
\end{tabular}

Tablo 3 incelendiğinde, $A B$ projesi yürütülen okullardaki öğretmenlerin $A B$ projelerinin okula katkılarına ve okul yöneticilerinin liderlik stillerine ilişkin algıları arasında anlamlı bir ilişki olduğu sonucuna ulaşıımıştır $(r=.36, p<.05)$. Çok Faktörlü Liderlik Ölçeği ve AB Projeleri Katkıları Değerlendirme Ölçeğine ait alt boyutlar arasında korelasyon değerlerine bakıldığında, en yüksek ilişkinin yabancı dil öğrenme alt boyutu ile dönüşümcü liderlik alt boyutu arasında olduğu ( $r=$ .38, $p<.01$ ); en düşük ilişkinin ise etkileşimci liderlik alt boyutu ile kurumsal gelişim alt boyutu arasında olduğu $(r=.15, p<.01)$ görülmektedir.

Araştırmanın dördüncü alt probleminde, $A B$ projesi yürütülen okullardaki öğretmenlerin algılarına göre okul yöneticilerinin liderlik stillerinin $A B$ projelerinin okula katkı düzeyinin anlamlı bir yordayıcısı olup olmadığı incelenmiştir. Söz konusu problemin çözümü için, Çok Faktörlü Liderlik Ölçeğinden ve $A B$ Projeleri Katkıları Değerlendirme Ölçeğinden elde edilen veriler kullanılmıştır. Yordanan değişken olarak $A B$ Projeleri Katkıları Değerlendirme Ölçeği toplam puanı, yordayıcı değişken olarak da çok faktörlü liderlik stili ölçeğinden elde edilen puanlar ele 
alınmıştır. Bu doğrultuda, verilerin çözümlenmesi için çoklu doğrusal regresyon analizi yapılmıştır.

$A B$ Projelerinin okullara olan katkılarının okul müdürlerinin liderlik stilleri tarafından yordanmasına ilişkin çoklu doğrusal regresyon analizi sonuçları Tablo 4 'te yer almaktadır.

Tablo 4. AB Projelerinin Okullara Olan Katkılarının Yordanmasına Ilişkin Çoklu Doğrusal Regresyon Analizi Sonuçları

\begin{tabular}{|c|c|c|c|c|c|c|c|c|c|c|}
\hline \multirow[t]{2}{*}{ Değişken } & \multicolumn{2}{|c|}{$\begin{array}{c}\text { Kurumsal } \\
\text { Gelişim }\end{array}$} & \multicolumn{2}{|c|}{$\begin{array}{c}\text { Kişisel/Mesleki } \\
\text { Gelişim }\end{array}$} & \multicolumn{2}{|c|}{$\begin{array}{l}\text { Sosyal } \\
\text { Gelişim }\end{array}$} & \multicolumn{2}{|c|}{$\begin{array}{l}\text { Yabancı Dil } \\
\text { Öğrenme }\end{array}$} & \multicolumn{2}{|c|}{ Kültürel Gelişim } \\
\hline & b & $p$ & b & $p$ & b & $p$ & b & $p$ & $b$ & $p$ \\
\hline Sabit & & ,000 & & ,000 & & ,000 & & ,000 & & ,000 \\
\hline Dönüşümcü liderlik & ,409 & ,000 & ,377 & ,000 & ,382 & ,000 & ,423 & ,000 & ,365 & ,000 \\
\hline Etkileşimci liderlik &,- 072 & ,103 &,- 011 & ,796 &,- 020 & 651 &,- 032 & ,467 &,- 025 & ,570 \\
\hline \multirow[t]{2}{*}{$\begin{array}{r}\text { Serbestlik tanıyan } \\
\text { liderlik }\end{array}$} & ,069 & ,072 & ,099 & ,010 & 072 & ,060 & 103 & ,007 & 125 & ,001 \\
\hline & \multicolumn{2}{|c|}{$R^{2}=, 13$} & \multicolumn{2}{|c|}{$R^{2}=, 13$} & \multicolumn{2}{|c|}{$\mathrm{R}^{2}=, 13$} & $R^{2}=, 15$ & $\begin{array}{l}15 \\
000\end{array}$ & \multicolumn{2}{|c|}{$R^{2}=, 12$} \\
\hline
\end{tabular}

Tablo 4'e göre, dönüşümcü liderliğin $A B$ Projeleri Katkıları Değerlendirme Ölçeğine ait kurumsal gelişim boyutunun anlamlı bir yordayıcısı olduğu görülmektedir $(\beta=, 409, t=8,985, p$ $=, 000)$. Buna göre, dönüşümcü liderlik boyutunda yaşanan bir puanlık değişim $A B$ Projeleri Katkıları Değerlendirme Ölçeğine ait kurumsal gelişim boyutunda ,409 puanlık değişime yol açmaktadır. Buna karşın etkileşimci liderliğin ve serbestlik tanıyan liderliğin AB Projeleri Katkıları Değerlendirme Ölçeğine ait kurumsal gelişim alt boyutunun anlamlı bir yordayıcısı olmadığı saptanmıştır ( $\beta=-, 072, t=-1,630, p=, 103 ; \beta=, 069, t=1,799, p=, 072)$. Çoklu doğrusal regresyon analizi sonucunda $A B$ Projeleri Katkıları Değerlendirme Ölçeğine ait kurumsal gelişim alt boyutunun toplam varyansın \%13'ünü açıkladığı görülmektedir. Diğer taraftan, dönüşümcü liderliğin $A B$ Projeleri Katkıları Değerlendirme Ölçeğine ait kişisel/mesleki gelişim boyutunun anlamlı bir yordayıcısı olduğu görülmektedir $(\beta=, 377, t=8,266, p=.000)$. Buna göre, dönüşümcü liderlik boyutunda yaşanan bir puanlık değişimin $A B$ Projeleri Katkıları Değerlendirme Ölçeğine ait kişisel/mesleki gelişim boyutunda ,377 puanlık değişime yol açmaktadır. Yine aynı tablodan, serbestlik tanıyan liderliğin AB Projeleri Katkıları Değerlendirme Ölçeğine ait kişisel/mesleki gelişim boyutunu anlamlı biçimde yordadığı görülmektedir $(\beta=, 099$, $\mathrm{t}=2,567, \mathrm{p}=.010$ ). Buna karşın etkileşimci liderlik boyutunun $\mathrm{AB}$ Projeleri Katkıları Değerlendirme Ölçeğine ait kişisel/mesleki gelişim boyutunun anlamlı bir yordayıcısı olmadığı saptanmıştır $(\beta=-, 011, t=-, 259, p=.796)$. Çoklu doğrusal regresyon analizi sonucunda $A B$ Projeleri Katkıları Değerlendirme Ölçeğine ait kişisel/mesleki gelişim boyutunun toplam varyansın \%13'ünü açıkladığı görülmektedir. Yine Tablo 4 incelendiğinde, dönüşümcü liderliğin AB Projeleri Katkıları Değerlendirme Ölçeğine ait sosyal gelişim boyutunun anlamlı bir yordayıcısı olduğu görülmektedir ( $\beta=, 382, t=8,378, p=.000$ ). Buna karşın etkileşimci liderliğin ve serbestlik tanıyan liderliğin $A B$ Projeleri Katkıları Değerlendirme Ölçeğine ait sosyal gelişim alt boyutunun anlamlı bir yordayıcısı olmadığı saptanmıştır $(\beta=-, 020, t=-, 453 p=, 651 ; \beta=, 072, t$ $=1,880, p=, 060)$. Çoklu doğrusal regresyon analizi sonucunda $A B$ Projeleri Katkıları Değerlendirme Ölçeğine ait sosyal gelişim boyutunun toplam varyansın \%13'ünü açıkladığı görülmektedir. Bununla birlikte, dönüşümcü liderliğin $A B$ Projeleri Katkıları Değerlendirme 
Ölçeğine ait yabancı dil öğrenme boyutunun anlamlı bir yordayıcısı olduğu görülmektedir ( $\beta=$ ,423, $t=9,406, p=.000$ ). Buna göre, dönüşümcü liderlik boyutunda yaşanan bir puanlık değişimin AB Projeleri Katkıları Değerlendirme Ölçeğine ait yabancı dil öğrenme boyutunda ,423 puanlık değişime yol açmaktadır. Yine aynı tablodan, serbestlik tanıyan liderliğin $A B$ Projeleri Katkıları Değerlendirme Ölçeğine ait yabancı dil öğrenme boyutunu anlamlı biçimde yordadığı görülmektedir $(\beta=, 103, t=2,714, p=.007$ ). Buna karşın etkileşimci liderlik boyutunun $A B$ Projeleri Katkıları Değerlendirme Ölçeğine ait yabancı dil öğrenme boyutunun anlamlı bir yordayıcısı olmadığı saptanmıştır $(\beta=-, 032, t=-, 728, p=, 467)$. Çoklu doğrusal regresyon analizi sonucunda $A B$ Projeleri Katkıları Değerlendirme Ölçeğine ait yabancı dil öğrenme boyutunun toplam varyansın \%15'ini açıkladığı görülmektedir.

Son olarak, dönüşümcü liderliğin AB Projeleri Katkıları Değerlendirme Ölçeğine ait kültürel gelişim boyutunun anlamlı bir yordayıcısı olduğu görülmektedir $(\beta=, 365, t=7,944, p=.000$ ). Buna göre, dönüşümcü liderlik boyutunda yaşanan bir puanlık değişimin AB Projeleri Katkıları Değerlendirme Ölçeğine ait kültürel gelişim boyutunda ,365 puanlık değişime yol açmaktadır. Yine aynı tablodan, serbestlik tanıyan liderliğin AB Projeleri Katkıları Değerlendirme Ölçeğine ait kültürel gelişim boyutunu anlamlı biçimde yordadığı görülmektedir $(\beta=, 125, t=3,233, p=$ .001). Buna karşın etkileşimci liderlik boyutunun AB Projeleri Katkıları Değerlendirme Ölçeğine ait kültürel gelişim boyutunun anlamlı bir yordayıcısı olmadığı saptanmıştır $(\beta=-, 025, t=-, 569, p=$ ,570). Çoklu doğrusal regresyon analizi sonucunda AB Projeleri Katkıları Değerlendirme Ölçeğine ait kültürel gelişim boyutunun toplam varyansın \%12'sini açıkladığı görülmektedir.

\section{SONUÇ TARTIŞMA VE ÖNERILER}

Bu bölümde, a) $A B$ projelerinin okullara sağladığı katkı düzeyi b) okul müdürlerinin liderlik stilleri ve c) bu $A B$ projelerinin okullara sağladığı katkı düzeyi ile okul müdürlerinin liderlik stilleri arasındaki ilişkiler ile ilgili elde edilen sonuçlar sıralanmakta ve tartışılmaktadır.

$A B$ projelerine katılım gösteren okullarda görev yapan öğretmenlerin $A B$ projelerinin okula sağladığı katkılara ilişkin algılarının ölçeğin tüm alt boyutlarında olumlu olduğu görülmüştür. Diğer taraftan, öğretmenlerin en yüksek düzeyde katılım gösterdikleri boyut kurumsal gelişim olurken, en düşük ortalama ise kültürel gelişim boyutunda gerçekleşmiştir. İlgili alanyazın incelendiğinde, $A B$ projelerinin çeşitli eğitim değişkenleri için olumlu ve faydalı olduğu sonucuna ulaşan çeşitli çalışmalar bulunmaktadır (Anıl, 2006; Aydoğmuş, 2013; Öztürk, 2015; Top, 2006; Topçu, 2011). Benzer şekilde, Kesik ve Balcı (2015) çalışmalarında AB projelerinin yürütüldüğü okullarda öğretmenlerin okullarını sağlıklı kurumlar olarak gördüğü sonucuna ulaşmıştır. Diğer yandan Kulaksız $\underline{(2010)}$ ise çalışmasında öğretmen algılarına göre $A B$ projelerinin eğitime henüz istenilen düzeyde katkı sağlamadığını vurgulamıştır. Araştırmada elde edilen bir diğer sonuca göre, $A B$ projesi yürütülen okullardaki öğretmenlerin bu projelerin katkılarına ilişkin algılarının ölçeğin alt boyutlarında cinsiyete göre anlamlı bir farklıık olmadığı görülmüştür. Bu çalışmanın aksine, Top'un (2006) Avrupa Birliği Eğitim ve Gençlik Programlarına ilişkin öğretmen ve yönetici algılarını incelediği çalışmada kadınların bu tür programların dil öğrenimini kolaylaştırdığına dair olumlu algılarının erkeklere oranla daha yüksek olduğu sonucuna ulaşmıştır. $A B$ projesi yürütülen okullardaki öğretmenlerin kıdem yılına göre farklılaşma durumuna bakıldığında, bu projelerin katkılarına ilişkin algılarının ölçeğin kişisel/mesleki gelişim, sosyal gelişim, yabancı dil öğrenme ve kültürel gelişim alt boyutlarında anlamlı bir farklılık göstermediği görülmüştür. Diğer taraftan, ölçeğin kurumsal gelişim alt boyutunda ise mesleki kıdem yılı 6-20 arasında olanlar lehine anlamlı bir fark oluşmuştur. Buna göre, 6-20 yıl arasında kıdeme sahip öğretmenlerin algılarının 21 ve üzeri yıl kıdeme sahip öğretmenlere göre daha yüksek olduğu görülmüştür. Bu bulgu, 6-20 yıl kıdeme sahip öğretmenlerin algılarının kıdem yılı daha yüksek olanlara göre $A B$ projelerinin kurumsal 
katkısının daha yüksek olabileceğine ilişkin algılarını göstermektedir. Bu bulgu, öğretmenlerin görevlerinde daha deneyimli hale geldikçe $A B$ projelerinin kurumsal açıdan katkılarını benimseme düzeylerinin azaldığı biçiminde yorumlanabilir. $A B$ projesi yürütülen okullardaki öğretmenlerin, bu projelerin okula sağladığı katkılara ilişkin algılarının ölçeğin kurumsal gelişim alt boyutunda branşa göre anlamlı bir fark olduğu görülmüştür. Bu çerçevede, öğretmenlerin branşına göre oluşan farklılığın hangi gruplar arasında gerçekleştiğini bulmak üzere yapılan LSD testi sonucuna göre sosyal bilgiler ve görsel sanatlar branşında görevli öğretmenlerin algılarının teknoloji ve tasarım branşındakilere göre daha yüksek olduğu görülmüştür. Ayrıca, Türkçe, matematik ve yabancı dil branşında görevli öğretmenlerin algılarının teknoloji ve tasarım ile din kültürü ve ahlak bilgisi branşındakilere göre daha yüksek olduğu izlenmiştir. Bunun yanında, fen bilimleri branşında görevli öğretmenlerin algılarının teknoloji ve tasarım, din kültürü ve ahlak bilgisi ve rehberlik branşındakilere göre daha yüksek olduğu bulunmuştur. Bu projelere katılım gösteren öğretmenlerin oranları incelendiğinde yaklaşık üçte ikilik kısmının Türkçe, matematik, fen bilimleri, sosyal bilgiler, yabancı dil ve görsel sanatlar branşında görev yaptıkları görülmektedir. Konu bu açıdan değerlendirildiğinde, bu altı branştaki öğretmenlerin proje faaliyetlerine daha fazla oranda katılmayla birlikte algılarının da daha yüksek olabileceği söylenebilir. Diğer taraftan din kültürü ve ahlak bilgisi branşındaki öğretmenlerin $A B$ proje faaliyetlerine katıımı sosyal bilgiler branşındakilere göre fazla olmasına karşın, bu branştaki öğretmenlerin $A B$ projelerinin kurumsal gelişime katkı boyutuna ilişkin görüşlerinin anlamlı düzeyde düşük çıkması ise dikkat çekicidir. Bu durum branşlardaki etkileşimin, din eğitiminde yeterli olmadığı, $A B$ eğitim programlarının, ülkemizinde verilen din eğitimine katkı sağlayacak düzeyde kapsayıcı olmadığı ya da din kültürü ve ahlak bilgisi öğretmenlerinin projelere karşı olumlu bir yaklaşım sergilemedikleri şeklinde açıklanabilir. Yine bu sonuç üzerinde, yabancı dil branşında görev yapan öğretmenlerinin $A B$ projelerinin dil öğrenimini kolaylaştırdığını düşünmelerinin etkisi olabilir. Literatürde $A B$ projelerinin yabancı dil öğrenimi üzerinde olumlu etkileri olduğuna dair çalışmalar yer almaktadır. Bunlardan birinde, Top (2006) Avrupa Birliği Eğitim ve Gençlik Programları üzerine gerçekleştirdiği çalışmasında dil öğrenimini kolaylaştırdığına ilişkin kadınların daha olumlu görüş belirtmelerine rağmen, öğretmen ve yöneticilerin program öncesi ve sonrası bilgi ve beceri düzeylerine ilişkin anlamlı bir farklılık olmadığını belirtmiştir. Anıl (2006) Leonardo da Vinci programı kapsamında gerçekleştirilen projelerin, faydalanıcıların proje bitiminde özgüven duygularının artığını ve uygulama öncesinde, uygulanırken ve proje sonrasında proje sahibi kurumların faydalanıcılara desteklerinin tam olduğunu belirlemiştir. Ayrıca, hareketlilik projeleri ile mesleki eğitime yenilikçi katkısının olduğu, teknoloji transferi sağladığı, öğrenci ve çalışanların özgüvenlerini artırma yönünden çok önemli katkıların olduğunu ifade etmiştir. Aydoğan ve Şahin (2006) Comenius okul ortaklıkları projesine katılan öğrencilerin, okula karşı olumlu duygu ve düşünceler geliştirdikleri, beklentilerinin oluştuğu, derslere katılımlarında artış olduğu, sorumluluk duygularının geliştiği sosyal faaliyetlere katılımın artığı, işbirliği becerilerin geliştiği ve problemlere daha farklı çözüm önerileri getirebildikleri, yabancı dil öğrenme arzularının yükseldiği ve diğer kültürlere yönelik olumsuz görüşlerinin değiştiğini belirtmişlerdir. Aydoğmuş $\underline{(2013)}$ ise araştırmasında Comenius Projelerinde görev alan öğretmenlerin, projelerin öğrenciler arasındaki takım çalışması ve bilgi iletişim araçlarını kullanabilme gibi 21. yüzyıl becerilerinin gelişmesinde etkili olmakla birlikte, diğer ülke katılımcılarının Türkiye'ye karşı düşüncelerini olumlu yönde etkilediği ve diğer farklı kültürleri öğrenmeye fırsatlar oluşturduğu görüşlerine sahip olduklarını ifade etmiştir. Topçu (2011) tarafından 2006-2010 yılları arasında Erasmus programına katılan 14 öğretim elemanıyla yarı yapılandırılmış görüşmeler yoluyla gerçekleştirdiği araştırması sonucunda programının tüm katılımcılar için faydalı olduğu ve Avrupa Birliği eğitim programlarının amaçlarına uygun olarak 
ileri düzeyde sonuçlar elde edildiğini ortaya koymuştur. Diğer taraftan, $A B$ projesi yürütülen okullardaki öğretmenlerin bu projelerin katkılarına ilişkin algılarının ölçeğin kişisel/mesleki gelişim, sosyal gelişim, yabancı dil öğrenme ve kültürel gelişim alt boyutlarında $A B$ proje faaliyetlerinde yer alma durumuna göre anlamlı bir fark olmadığı, kurumsal gelişim alt boyutunda ise anlamlı bir fark olduğu görülmüştür. Bu çerçevede, kurumsal gelişim boyutuna ilişkin öğretmen algılarının proje faaliyetlerinde yer alanlar lehine daha yüksek olduğu söylenebilir. Bu sonuç branş açısından oluşan farklılaşma ile birlikte değerlendirildiğinde, $A B$ proje faaliyetlerine katılan öğretmenlerin bu projelerin kurumsal gelişime yönelik katkılarını daha fazla benimsediklerini göstermektedir. Diğer taraftan, $A B$ projesi yürütülen okullardaki öğretmenlerin bu projelerin katkılarına ilişkin algılarının ölçeğin kurumsal gelişim, kişisel/mesleki gelişim, sosyal gelişim, yabancı dil öğrenme ve kültürel gelişim alt boyutlarında öğrenim düzeyine göre anlamlı bir fark olmadığı görülmüştür.

Okul müdürlerinin hangi liderlik stilini daha yüksek düzeyde gösterdiklerini belirlemek üzere ugulanan Çok Faktörlü Liderlik Ölçeği'nden elde edilen verilerin analizi sonucunda, öğretmenlerin en yüksek düzeyde algıladıkları stilin dönüşümcü liderlik olduğu en düşük düzeyde algıladıkları stilin ise serbestlik tanıyan liderlik boyutunda yaşandığı görülmüştür. Okul müdürlerinin dönüşümcü liderliğe ilişkin davranışlarını ağırlıklı olarak sergilediklerine ilişkin algıların daha yüksek düzeyde olması, olumlu olarak değerlendirilebilir. $A B$ projesi yürütülen okullarda okul müdürlerinin bu projelerin hazırlanması, uygulanması ve sonuçlandırılması aşamalarında yasal yetkili olduğu ve bu çerçevede öğretmenler tarafından dönüşümcü liderlik davranışlarının daha fazla algılanmasına sebep olabileceği söylenebilir. Diğer taraftan, AB projesi yürütülen okullardaki öğretmenlerin görev yaptıkları okulların müdürlerinin liderlik stillerine ilişkin algılarının, ölçeğin dönüşümcü liderlik ve etkileşimci liderlik alt boyutlarında erkekler lehine anlamlı düzeyde daha yüksek olduğu görülmüştür. Araştırmanın bu bulgusu Taş ve Çetiner'in (2011) çalışmalarının bulgusundan farklıdır. Taş ve Çetiner'in (2011) çalışmasının sonucuna göre kadın öğretmenlerin okul müdürlerinin dönüşümcü liderlik davranışlarına ilişkin algıları erkek öğretmenlere göre daha olumludur. Öte yandan, okul müdürlerinin dönüşümcü liderlik davranışlarına ilişkin öğretmen algılarında insiyete göre farklılık olmadığı sonucuna ulaşan çalışmalar da vardır (Çetiner, 2008; Çobanoğlu, 2003; Eryılmaz, 2006; Oran, 2002). Ölçeğin serbestlik tanıyan liderlik alt boyutunda ise cinsiyet açısından anlamlı bir farklılık oluşmamıştır. $A B$ projesi yürütülen okullardaki öğretmenlerin görev yaptıkları okulların müdürlerinin liderlik stillerine ilişkin algılarının ölçeğin dönüşümcü liderlik, serbestlik tanıyan liderlik ve etkileşimci liderlik alt boyutlarında mesleki kıdeme göre anlamlı bir fark oluşmamıştır. Ayrıca, AB projesi yürütülen okullardaki öğretmenlerin görev yaptıkları okulların müdürlerinin liderlik stillerine ilişkin algıları, ölçeğin dönüşümcü liderlik, serbestlik tanıyan liderlik ve etkileşimci liderlik alt boyutlarında branşa göre farklılaşmamaktadır. Çalışmanın bu bulgusu Töremen ve Yasan'ın (2010) araştırmalarında ulaştığı "öğretmenlerin okul müdürlerinin dönüşümcü liderlik davranışlarına yönelik algıları branşlarına göre anlamlı farklıık göstermemektedir" sonucu desteklemektedir.

Araştırmanın okul müdürlerinin liderlik stilleri ile $A B$ projelerinin okullara sağladığı katkılar arasındaki ilişkilere ilişkin sonuçları, okul yöneticilerinin dönüşümcü ve etkileşimci liderlik alt boyutu ile $A B$ projelerinin katkıları arasında pozitif yönde ve anlamlı bir ilişki olduğunu göstermektedir. Buna göre okul yöneticilerinin bu iki boyuttaki davranışları arttıkça $A B$ projelerinin okula olan katkıları da artmaktadır. Araştırma kapsamında yapılan çoklu doğrusal regresyon analizi sonucunda dönüşümcü liderlik alt boyutunun $A B$ projelerinin okula katkı düzeyini anlamlı biçimde yordadığı görülmüştür. Buna göre, dönüşümcü liderlik boyutunda yaşanan bir puanlık değişimin $A B$ projelerinin okula katkı düzeyinde ,439 puanlık değişime yol açmaktadır. Bununla birlikte, serbestlik tanıyan liderliğin $A B$ projelerinin okula katkı düzeyini anlamlı biçimde yordadığı saptanmıştır. Buna karşın etkileşimci liderlik boyutunun $A B$ projelerinin okula katkı düzeyinin anlamlı bir yordayıcısı olmadığı görülmüştür. Dönüşümcü liderliğin ise $A B$ Projeleri Katkıları Değerlendirme Ölçeğine ait kurumsal gelişim, kişisel/mesleki 
gelişim, sosyal gelişim, yabancı dil öğrenme ve kültürel gelişim boyutlarını anlamlı biçimde yordadığı görülmüştür. Ayrıca, Serbestlik tanıyan liderliğin AB Projeleri Katkıları Değerlendirme Ölçeğine ait kişisel/mesleki gelişim, yabancı dil öğrenme ve kültürel gelişim boyutlarını anlamlı biçimde yordadığı saptanmıştır. Buna karşın etkileşimci liderlik boyutunun AB Projeleri Katkıları Değerlendirme Ölçeğine ait tüm alt boyutların anlamlı bir yordayıcısı olmadığı saptanmıştır.

\section{Öneriler}

Bu araştırma uluslararası düzeyde yürütülen Erasmus+ kapsamındaki projeleri konu edinmiştir. Bununla birlikte ulusal düzeyde yürütülen projelerin etkilerinin incelenmesine dönük çalışmaların yapılması önerilmektedir. Bu çalışma kesitsel veriler kullanılarak yürütülmüştür. Özellikle $A B$ projelerinin iki ya da üç yıl sürdüğü düşünüldüğünde benzer çalışmanın birkaç yılı kapsayacak biçimde boylamsal olarak tasarlanması önerilebilir. Araştırmada okul müdürünün liderlik stilleri ile $A B$ projelerinin katkıları arasındaki ilişkisi incelenmiştir. $A B$ projelerini etkileyebilecek farklı değişkenler ile yeni çalışmalar yapılabilir. Benzer bir çalışmanın $A B$ projesine katılan öğrencilerin algılarına dayalı biçimde yürütülmesi önerilebilir. Bu araştırma belge taraması, gözlem, görüşme gibi farklı türden veriler toplanarak yürütülebilir.

Okul müdürlerinin liderlik stilleri ile $A B$ projelerinin okullara sağladığı katkı arasındaki anlamlı düzeyde en yüksek ilişkinin yabancı dil öğrenme alt boyutu ile dönüşümcü liderlik alt boyutu arasında olduğu görülmüştür. Araştırmada dönüşümcü liderlik boyutunun etkileşimci liderlik boyutuna göre öğretmenler tarafından daha yüksek düzeyde algılandığı saptanmıştır. Yine, dönüşümcü liderlik alt boyutu ile $A B$ projelerinin katkılarına yönelik alt boyutları arasındaki pozitif yönde ilişkiler ortaya konulmuştur. Bu kapsamda, $A B$ projesi yürütmüş okul müdürlerinin diğer okul müdürlerine bu deneyimlerini paylaşabilecekleri öğrenme ortamları oluşturulmalıdır. Araştırma kapsamında Türkçe, matematik, fen bilimleri, sosyal bilgiler ve yabancı dil branşlarında görev yapan öğretmenlerin $A B$ proje faaliyetlerine katılma durumu diğerlerine göre daha fazla olduğu görülmüştür. Bu çerçevede, projelerin hedef kitlesinin diğer branşları da kapsayacak biçimde genişletilmesi gerekmektedir. Bu çalışmada, öğretmen algılarına göre en düşük ortalamanın $A B$ projelerinin velilerin okula katılımını ve desteğini arttırmada konusunda yaşandığı görülmüştür. Bu çerçevede, okullarda velilere yönelik projelerin daha fazla uygulanması ve dolayısıyla velilerin proje faaliyetleri içerisinde daha fazla yer alması gerekmektedir.

\section{KAYNAKÇA}

Aksu, A. (2015). Adaptation of Multifactor Leadership Questionnaire (MLQ) into Turkish, VIII. European Conference on Social and Behavioral Sciences, September 3-6, 2015 - Belgrade, Serbia.

Anıl, O. (2006) Leonardo Da Vinci Projesinin (hareketlilik) Mesleki Eğitime Katkısı (Yayımlanmamış Yüksek Lisans Tezi). Gazi Üniversitesi Fen Bilimleri Enstitüsü, Ankara.

Aydoğan ve Şahin (2006) Comenius Okul Ortaklıkları Projelerinin, Comenius Amaçlarının Gerçekleşmesine Katkısı Kuram ve Uygulamada Eğitim Yönetimi Güz 2006, Sayı 48, ss: 455-480. 
Aydoğmuş, M. (2013). Öğretmen algısına göre Comenius projelerinin Amacına Uygun Gerçekleşme Düzeyinin Bazı Değişkenler Açısından Incelenmesi. Yayımlanmamış Yüksek Lisans Tezi. Konya: Necmettin Erbakan Üniversitesi, Eğitim Bilimleri Enstitüsü.

Burgaz, B., \& Turan, S. (2015). The Features of Schools which Conducted a Comenius Project and Evaluation of Features in terms of Collaborative Leadership Characteristics. Procedia-Social and Behavioral Sciences, 174, 338-346.

Council of the European Union (2003). Council Conclusions on Reference Levels of European Average Performance in Education and Training (Benchmarks). EDUC 83, 8981/03, 2003. 5-6 May 2003, Brussels.

Council of the European Union. (2009). Council Conclusions of 12 May 2009 on a strategic framework for European cooperation in education and training (ET 2020). Official Journal of the EU (2009/C 119/02).

Çetiner, A. (2008). Illköğretim Okulu Müdürlerinin Dönüşümcü Liderlik Davranışlarını Gösterme Düzeylerine ilişkin Öğretmen algıları (Burdur illi örneği). Yayımlanmamış yüksek lisans tezi, SDÜ. Sosyal Bilimler Enstitüsü, Isparta.

Çobanoğlu, F. (2003). Ilköğretim Yöneticilerinin Dönüşümcü Liderlik Davranışları. Yayımlanmamış yüksek lisans tezi, Pamukkale Üniversitesi, Sosyal Bilimler Enstitüsü, Denizli.

Eryılmaz, F. (2006). Endüstri Meslek Lisesi Okul Müdürlerinin Dönüşümcü Liderlik Özelliklerine Sahip Olma Düzeyleri (Ankara ilii Örneği). Yayımlanmamış Yüksek Lisans Tezi, Gazi Üniversitesi Eğitim Bilimleri Enstitüsü, Ankara.

Gülsen, İ. (2008). Okul Yöneticilerine Göre Avrupa Birliği Comenius Programı Okul Ortaklıkları Projelerinin Etkililiği. Yayımlanmamış Yüksek Lisans Tezi, Ankara: Ankara Üniversitesi.

Janiunaitè, B. (2005). The Model of İnnovation Implementation in Action: Challenges for Educational Leadership. Paper presented at the European Conference on Educational Research, University College Dublin, 7-10 September 2005. [Çevrim-içi: http://www.leeds.ac.uk/educol/documents/150402.htm, Erişim tarihi: 10 Temmuz 2019.].

Kamber, A. T. (2007). Avrupa Birliği Destekli Mesleki Eğitimi Güçlendirme Projesi (MEGEP) pilot mesleki teknik ortaöğretim okullarındaki proje kapsamında görevli yönetici ve öğretmenlerin proje hakkında algıları üzerine bir araştırma (Marmara Bölgesi örneği). Yayımlanmamış Yüksek Lisans Tezi, İstanbul: Yeditepe Üniversitesi.

Karasar, N. (2009). Bilimsel Araştırma Yöntemi. (20. Baskı). Ankara: Nobel Yayın Dağıtım.

Kavak, Y. (2010). 2050'ye Doğru Nüfusbilim ve Yönetim: Eğitim Sistemine Bakış. (2. Baskı). Türk Sanayici ve İşadamları Derneği ve Birleşmiş Milletler Nüfus Fonu. İstanbul: TÜSIAD.

Kesik, F. ve Balcı, E. (2015). Avrupa Birliği projelerine Katılım Gösteren Okulların Sağlığına İlişkin Öğretmen Algıları. Abant İzzet Baysal Üniversitesi Eğitim Fakültesi Dergisi, 15(2), 163-183.

Kulaksız, E. (2010). Avrupa Birliği Comenius Programlarının Türkiye'deki uygulamasına ilişkin katılımcı algıları. Yayımlanmamış Doktora Tezi, Kocaeli: Kocaeli Üniversitesi, Sosyal Bilimler Enstitüsü.

Oran, N. (2002). Illköğretim ve Ortaöğretim Okul Yöneticilerinin Dönüşümsel Önderlik Özelliklerine Ilişkin Öğretmenlerin Algı ve Beklentileri. Yayımlanmamış Yüksek Lisans Tezi, Trakya Ünv. SBE, Edirne.

Öztürk, E. (2015). Avrupa Birliği Comenius Programı'na katılan öğretmenlerin hareketlilik programının etkililiğine ilişkin algılarının değerlendirilmesi. Yayımlanmamış Yüksek Lisans Tezi. Uşak: Uşak Üniversitesi, Sosyal Bilimler Enstitüsü.

Taş, A. ve Çetiner, A. (2011). Ortaöğretim Okulu Müdürlerinin Dönüşümcü Liderlik Davranışlarını Gerçekleştirme Durumlarına İlişkin Öğretmen Algıları. Türk Eğitim Bilimleri Dergisi, 9(2), 369-392.

Top, V. (2006). Avrupa Birliği Eğitim ve Gençlik Programlarına ilişkin öğretmen ve yönetici algıları. Yayımlanmamış Yüksek lisans Tezi, Elazığ: Fırat Üniversitesi Sos-yal Bilimler Enstitüsü.

Topçu, İ. (2011). Avrupa birliği Eğitim Programlarından Erasmus Programına Katılan Akademisyenlerin İzlenimleri. Cumhuriyet Üniversitesi Sosyal Bilimler Dergisi, (35), 1, 8-17.

Toprakcl, E. (2004) The European Union Action Programme in the Area of Education (A Comparative Analysis). Education and Science (TED) January 2004, vol.29, No:131. pp.83-

92. http://egitimvebilim.ted.org.tr/index.php/EB/article/view/5092/1170

Toprakcl, E. (2006) "European Union, European Dimension in Education and National Education Goals of the Member Countries (According to the official documents of European Union)" AÜ. Bayburt Eğitim Fakültesi Dergisi, Yıl 1, Sayı 1(2006) 1- 19.

https://arastirmax.com/en/system/files/dergiler/111633/makaleler/1/1/arastirmax-avrupabirligi-egitimde-avrupalilik-boyutu-uye-ulkelerin-ulusal-egitim-amaclari-avrupa-birliginin-resmidokumanlarina-gore.pdf 
Toprakcı, E. ve Yılmaz, G. (2014) Avrupa Birliği'nin Türkiye'ye Yönelik İlerleme Raporlarının Eğitim Başlığındaki Tespitler İle MEB 2010-2014 Stratejik Planı'nın Karşılaştırılması" Yeni Türkiye Dergisi, Eğitim Özel Sayısı Mayıs-Haziran 2014 Yıl:10, Sayı:58, ss.355-370 [Çevrim-içi: http://www.erdaltoprakci.com.tr/wp-content/uploads/2018/06/avrupa-birli\%C4\%9Fi-vemeb.pdf Erişim tarihi: 20 Ekim 2018.].

Töremen, F ve Yasan, T. (2010). İlköğretim okulu yöneticilerinin dönüşümcü liderlik özellikleri (Malatya ili örneği). Pamukkale Üniversitesi Eğitim Fakültesi Dergisi, 28(2), 27-39.

UA (Ulusal Ajans) (2014). Erasmus+ program rehberi. [Çevrim-içi: http://www.ua.gov.tr/docs/defaultsource/hayatboyu-\%C3\%B6\%C4\%9 Frenme/erasmus- -program_-rehberi.pdf?sfvrsn=0, Erişim tarihi: 20 Ekim 2016.].

UN (United Nations) (2003). Indicators for monitoring the millennium development goals: Definitions, rationale, concepts and sources. New York, NY: United Nations Development Group.

UNESCO (2014). Towards indicators for a post-2015 education framework. (version 2). Montreal, Quebec: UNESCO-UIS.

UNESCO (United Nations Educational, Scientific and Cultural Organization) (2000). The Dakar framework for action. Education for all: Meeting our collective commitments. World Education Forum, 26-28 April 2000, Dakar, Senegal.

WCEFA (World Conference on Education for All) (1990). Meeting Basic Learning Needs: A Vision for the 1990s. New York: UNICEF. 


\title{
The Relationship Between Leadership Styles of School Principals and Contribution Level of European Union Projects to The School
}

\author{
Vefa Bardakcı \\ MEB-Turkey \\ vefabardakci@hotmail.com
}

\author{
Prof. Dr. Ali Aksu \\ Dokuz Eylul University-Turkey \\ ali.aksu@deu.edu.tr
}

\begin{abstract}
This study intends to evaluate the relationship between the leadership styles of school principals and contribution level of European Union (EU) projects to the school in terms of the perceptions of secondary school teachers in Ankara. It's a descriptive study. Secondary school teachers having conducted at least one EU Project in Ankara in 2016-2017 academic year form the sample of the study. "Multi-factorial Leadership Scale" and "The Evaluation Scale of Contributions of European Union Projects" have been used in the study. According to the results of leadership styles of school principals, transformational leadership is the dimension teachers have utmost participation, whereas laissez faire leadership dimension is the one having the least participation. The study indicates that working at schools conducting EU projects creates positive perceptions on the contributions of those projects. On the other hand, these perceptions do not vary in the aspects of the gender and education levels of teachers. Multiple Linear Regression Analysis results display that the subdimensions of transformational amd lassiez faire leadership styles predict the contribution level of $E U$ projects to the school significantly.
\end{abstract}

Keywords: School, Leadership, leadership styles, EU projects

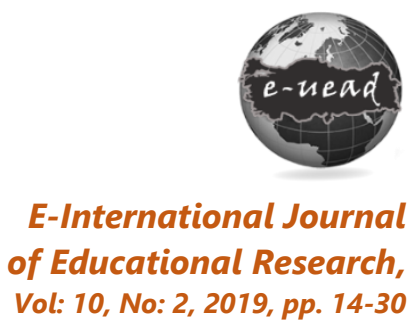

DOI: 10.19160/ijer.468460

\section{Suggested Citation:}

Bardakçı, V. \&. Aksu, A. (2019). The Relationship Between Leadership Styles of School Principals and Contribution Level of European Union Projects to The Schol, E-International Journal of Educational Research, Vol: 10, No: 2, 2019, pp. 14-30, DOI: 10.19160/ijer.468460 


\section{EXTENDED ABSTRACT}

Problem: School projects conducted in Turkey through the targets of European Council are perceived as initiatives improving the relations among school stakeholders; enabling them to gain collaboration skills; enhancing the parents' participation in school activities; providing students who take part in projects with involvement in academic, social and artistic works; improving the students' self confidence through giving them chance to display what they learn; providing the participants with learning and investigating the values of not only EU countries but their own countries as well and encouraging to learn langauges. It can be put forward that the school projects offering such opportunities and being administered well can supply contributions to schools. Therefore, evaluating the leadership styles of school principals, sustainability of projects and EU projects have been regarded worth studying in terms of their contributions to schools.

In the study, it has been aimed to answer the questions "What are the perceptions of teachers at schools administering EU projects on contributions of these projects to the school and leadership styles of school principals? Do the perceptions of teachers show significant difference in different variables? What is the relationship between the perceptions of teachers on contributions of EU projects to the school and leadership styles of school principals?"

Method: Since it has been intended to evaluate the perceptions of teachers working at schools in Ankara that conducted EU projects on contributions of these projects to the school and leadership styles of school principals, relationship between those variables and the variables depending on this study, it is a descriptive study. Population of the study has been determined as the schools in Ankara which have been involved at least in one EU Project in 2016-2017 academic year. These schools have been determined based on the list obtained from National Agency and the other schools have been excluded from the study. In accordance with the information obtained, it has been spotted that 10 projects in 2014, 4 projects in 2015 and 7 projects in 2017 were approved within the scope of Erasmus +. Thus, the population of the study includes totally 971 teachers working at 21 official secondary schools. It was intended to reach the population entirely; however, $80,1 \%$ of the population could have been included in the study. To provide the quantitative data of the study, Multi-factorial Leadership Scale" and "The Evaluation Scale of Contributions of European Union Projects" have been implemented.

Findings: It has been revealed that the perceptions of teachers working at schools which have conducted EU projects are positive towards the contributions of projects to the school in all subdimensions of the scale. On the other hand, teachers have the maximum participation in institutional development, while the least participation is seen in cultural development dimension. About the leadership styles of school principals, the style perceived highest is tramsformational, yet, the least perceived one is laissez faire. That the results', indicating the behaviours of school principals on transformational leadership style, having predominantly been perceived can be considered as positive. It can also be supposed that the school principals are the legal authorities in preparing, implementing and evaluating the projects; thus, this might result in the fact that teachers perceive them as transformational leaders. Relationship between the leadership styles of the school principals and contribution of EU projects to the school is significantly positive in terms of the subdimensions of transformational and interactional leadership styles. In accordance with this, as long as the behaviours of school principals in these two dimensions improve, contributions of EU projects to school increase as well. According to the Multiple Linear Regression Analysis, 
subdimension of transformational leadership predicts the contribution level of EU projects to the school significantly. That is, one-point-change in transformational leadership dimension results in $a, 439$-point-change in the contribution level of EU projects to the school. Moreover, laizzes faire leadership predicts the contribution level of EU projects to the school significantly. However, it has been determined that the interactional leadership dimension is not a significant predictor of contribution of EU projects to the school. Transformational leadership predicts institutional, personal/professional, social development; learning a foreign language and cultural development significantly. Additionally, laizzes faire leadership is a significant predictor of personal/professional development, learning a foreign language and cultural development dimensions in the "The Evaluation Scale of Contributions of European Union Projects". Nevertheless, interactional leadership is not a significant predictor of all subdimensions of that scale. 